\title{
Training on Packaging and Marketing Produk for MSMEs in Kasemen
}

\author{
Solehatin Ika Putri ${ }^{1}$, Muhammad Johan Widikusyanto², Galih Ginanjar Saputra ${ }^{3}$ \\ 1,2,3 Universitas Sultan Ageng Tirtayasa, Indonesia \\ putri.solehatin@untirta.ac.id $^{1)}$
}

\begin{abstract}
Abstrak
Masalah pemasaran produk menjadi kendala terbesar dari sejumlah UMKM. Hal ini dikarenakan minimnya pengetahuan masyarakat mengenai proses pemasaran dan aktivitas - aktivitas penting sebelum pemasaran salahsatunya yaitu pengemasan produk. Pelaksanaan dilakukan melalui pelatihan dan praktik langsung mengenai pengemasan dan pemasaran produk. Adapun hasil dari kegiatan adalah mitra mampu memahami pentingnya pengemasan produk dan pemberian label/merek serta mengetahui cara membuat kemasan produk agar produk semakin menarik dan memiliki identitas. Selain itu mitra juga mampu memahami pentingnya pemasaran produk dan mengetahui cara memasarkan produk secara efektif untuk meningkatkan penjualan dan menambah penghasilan.
\end{abstract}

Kata kunci: Pengemasan Produk, Pemasaran Produk, UMKM

\section{Abstract}

The problem of marketing product is the biggest obstacle for a number of MSMEs. This is due to the lack of public knowledge about the marketing process and important activities before marketing, one of which is product packaging. Implementation is carried out through training and practice regarding product packaging and marketing. The results of the activity are partners are able to understand the importance of product packaging and labeling/branding and know how to make product packaging so that the product is more attractive and has an identity. In addition, partners are also able to understand the importance of product marketing and know how to market products effectively to increase sales and increase income.

Keywords : Marketing Product, MSMEs, Packaging Product

\section{Introduction}

Micro, small and medium enterprises (MSMEs) in Banten Province are faced with several difficulties in running their business. The difficulties faced by MSME entrepreneurs can become obstacles that hinder the progress and development of their business. According to the Central Statistics Agency (BPS) of Banten Province in 2017 there were 7 types of difficulties faced by MSMEs as presented in table 1. Of the seven types of difficulties, marketing problems became the biggest obstacle for a number of MSMEs in Banten Province. This is indicated due to the lack of public knowledge about the marketing process and important activities before marketing a product/service is carried out. 


\begin{tabular}{cc}
$\begin{array}{c}\text { Table 1. Types of difficulties for Micro Small Industry } \\
\text { Food Business in Banten Province }\end{array}$ \\
\hline Number of Difficulties & Business Activities \\
\hline Raw Material & 6.684 \\
Marketing & 15.733 \\
Capital & 4.732 \\
Fuel/Energy & 4.141 \\
Transportation & 755 \\
Skills & 1.015 \\
Labor Wages & 2.059 \\
Other & 582 \\
\hline
\end{tabular}

BPS Banten Province, 2017

Terumbu Village is one of the villages included in the sub-district with the largest number of poor people in Serang City, namely Kasemen District. In 2015, from the 40 percent indicator, there were around 10,325 poor households in Kasemen District. This number is more than other sub-districts in Serang City (Banten News, 2017). Most of the housewives in the Terumbu Village are micro-enterprises who produce and sell traditional snacks. Based on the Standard Classification of Indonesian Business Fields (KBLI) in 2015 Perka 2017, Micro and Small businesses are spread over $24 \mathrm{KBLI}$. The food industry has the largest number, namely 37.31 percent or 39,438 business units. In addition, these Micro and Small Enterprises are generally characterized by minimal capital, flexibility in running a business, the products/services produced are close to the needs of the community, and the use of local resources. In addition, according to Darwanto et al., (2017) MSMEs are one of the leading sectors that contribute to the development of the national economy. However, many MSMEs according to Subali et., al, (2020) find problems in their economic activities, in general the problems faced are the long production process and the product packaging is still simple and conventional.

The packaging of a product will greatly affect the consumer's decision to buy the product or not. This is in accordance with the opinion of Sudodo, Yandri (2019) that product packaging has a significant effect on purchasing decisions on MSME products. In line with Sudodo, Anisa, Rosyida (2017) also stated that there is an influence between product packaging on consumer purchasing decisions. Based on this, the packaging of MSME products, especially products produced by the Terumbu Village community, must be made as attractive as possible to improve consumer decisions to buy. This purchase decision will also have an impact on sales volume and ultimately on increasing income. Another study conducted by Fitriani (2020) concluded that packaging has a significant influence on Sales Volume.

In addition to packaging issues, the product marketing process also needs to be improved to increase sales. If sales increase, the production process will continue and increase the production of processed food in the Terumbu Village. This is in line with the opinion of Khasanah, Dwi Rohmawati, Sunarto and Erry. (2021) that marketing activities have an effect on increasing production results.

The above phenomenon is the main basis for us to carry out community service through training, we take the initiative to increase the skills of the Terumbu Village community to be able to develop their business by supporting capacity building in terms of product packaging and marketing. This activity takes the form of training on product packaging with labels and brands as well as training on effective product marketing to penetrate a wider market. The target of the service participants are micro business actors, namely housewives in the Terumbu village, Kasemen District, Serang City. The 
output target to be achieved during this empowerment activity is the formation of understanding and ability regarding the importance of product packaging and marketing.

\section{Implementation Method}

The implementation of service activities is carried out through preliminary methods, training through demonstrations and direct practice. The introduction was carried out as an early stage of the approach and to explore information on the products produced by the reef village community, namely spring rolls of bamboo shoots and shredded papaya. The problem with the partners is that the products produced are packaged modestly and without a brand identity or label and the marketing method is only limited to the reef village area. This training will include exposure and practice on packaging techniques for processed food products and how to market them.

The instructor's initial training process explained the importance of product packaging through product and brand identity. The trainees observe the whole process and at the end of the activity, the participants practice directly packing the product and attaching the label. Furthermore, there is an explanation of how to market products that are effective and can reach the wider community. The training provided has the following stages:

\section{A. Product Packaging}

1) Pack frozen spring rolls or shredded papaya neatly. The simple way is to use mica plastic, neatly arranged, labeled and insulated the edges. Or you can use ordinary thick plastic, neatly arranged, labeled.

2) Seal the lid of the package by using a sealer neatly. Sealers for thick plastic home businesses have a price of around 150 thousand.

3) Spring rolls can be packed with lots or small packs of 2, 3, 10, etc. Packaging sizes like this give buyers the choice of packaging they want.

4) The shelf life of the packaging can be longer by using a vacuum sealer system (airtight). Packaging with a vacuum sealer can last up to 3 months in the freezer.

5) Labeling is important to increase Branding and increase Selling power. The label must contain the manufacturer's brand. Brand names and logos should be good, easy to remember, easy to pronounce and create the desired image.

Labels can be made easily and cheaply but must still contain elements of good branding. The cheapest is to use plain paper. Designed on a computer, printed, photocopied then cut to size and put into packaging. A better label is to make it on waterproof sticker paper. Previously it had to be designed as good as possible even though it was simple and then printed on sticker paper. Furthermore, cut as desired, can be square, round, oval or other shapes. After that the sticker label is affixed to the sealed package.

B. Product Marketing

1) Understanding the market

Collecting data on the needs and desires of consumers of processed products, especially products made from bamboo shoots and papaya as well as geographic and demographic data of consumers.

2) Formulate marketing strategy

Perform consumer grouping based on previously collected data. Grouping based on geographic and demographic data. Next, determine the segment to be served or the destination for selling processed products. Then determine the positioning or image of the product to be delivered or implanted in the target market. 
3) Designing marketing program

Determine products (attributes, brands, packaging, labels and supporting services), prices, distribution and promotions based on the formulation of marketing strategies that have been prepared previously.

4) Build customer relationship

Creating satisfaction and good communication through existing media such as social media or sms can help build mutually beneficial long-term customer relationships. Collect and analyze customer databases to understand and satisfy customers. Building long term customer relationships also means building customer loyalty.

\section{Results and Discussion}

This community service activity was carried out in the reef village on September 13,2020 , through the stages of activities, namely the presentation of the importance of product packaging, product packaging practices and product marketing presentations. In addition to explaining the importance of having a brand listed on the packaging label. It also explains how to create a brand in a simple and easy way. In addition, the contact number must be listed on the packaging label. Packaging labels can be made yourself using the help of a computer or you can also pay for packaging label making services. In this training, ready-made sticker packaging labels were shown. Participants were also explained how to use sealers in order to produce good and strong packaging seals. The product packaging practice encouraged participants to be actively involved in attaching the label sticker that had been made to the package filled with bamboo shoot spring rolls and shredded papaya. Furthermore, participants practice sealing the packaging using a sealer.

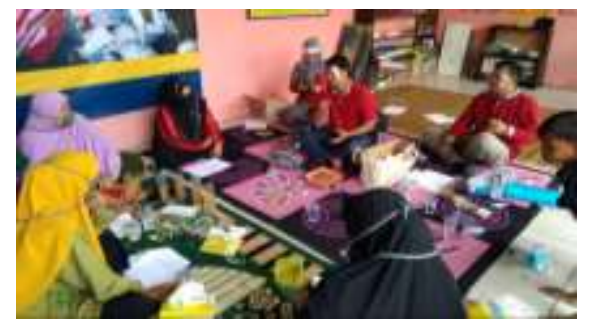

Figure 1. Product Packaging Exposure
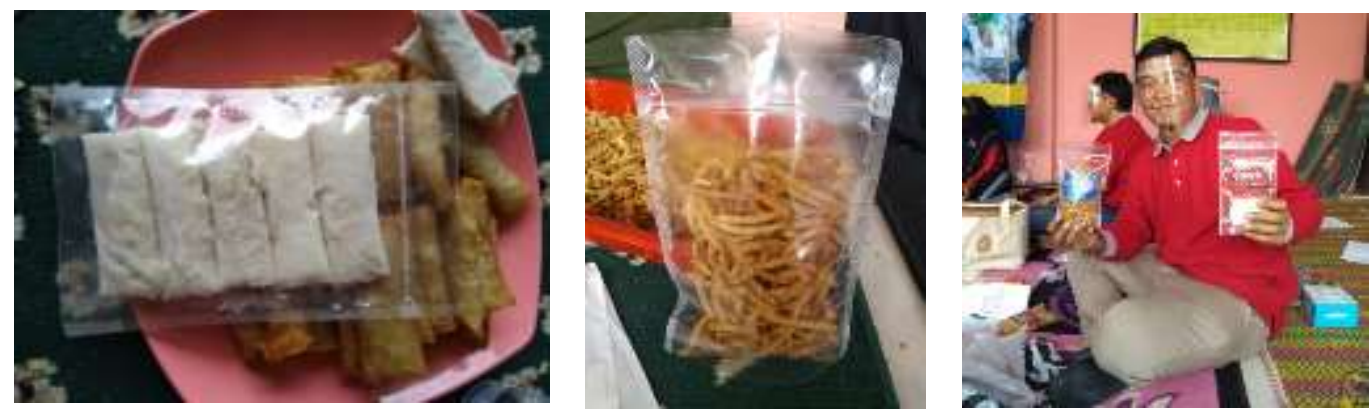

Figure 2. Product Packaging Practices

Product marketing presentations are carried out by means of participants receiving handouts containing product marketing materials. Then the presenters explained how to market the products they have made effectively so that they can penetrate a wider market and can become additional income for the family. 


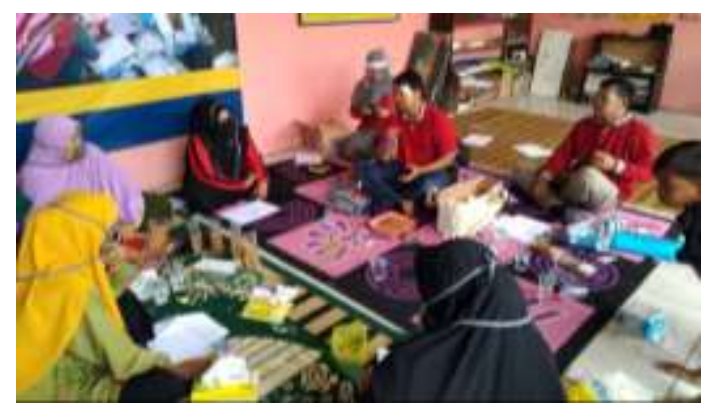

Figure 3. Product Marketing Exposure

Community service activities ended with closing. The training activity was closed with the delivery of the benefits of the training that had been carried out by the PKM team as well as thanks for the participation and assistance of residents so that PKM activities could run smoothly. The partners also gave closing words containing thanks and apologies if there were deficiencies in helping the smooth running of activities and the hope that the results of the training could help increase family income.

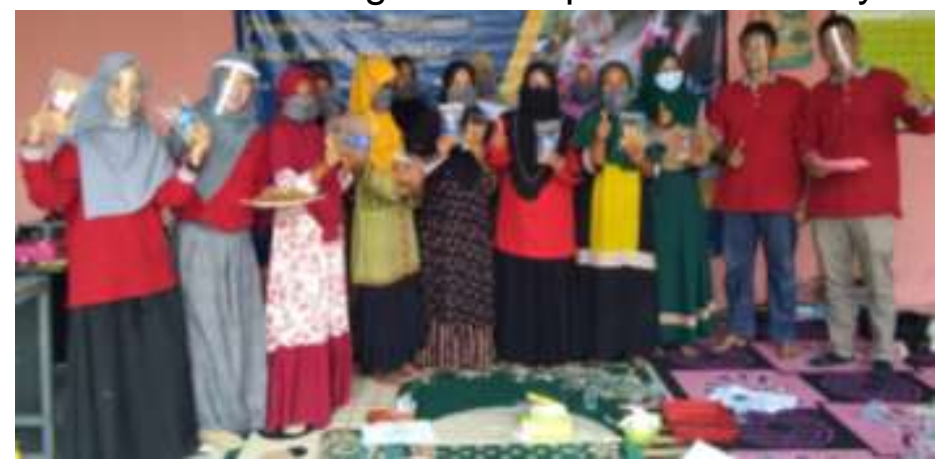

Figure 4. Photo with Participants

\section{Conclusion}

The service activities that have been carried out have resulted in the conclusion that partners are able to understand the importance of product packaging and labeling/branding and know how to make product packaging so that the product is more attractive and has an identity. In addition, partners are also able to understand the importance of product marketing and know how to market products effectively to increase sales and increase income.

\section{Acknowledgment}

The author would like to thank Sultan Ageng Tiritayasa University for providing financial support for this service activity and also for the community in Terumbu Village, Kasemen District, Serang City - Banten.

\section{Reference}

Anisa, Rosyida. (2017). Pengaruh Kemasan Produk dan Merk Teh Celup Sariwangi terhadap Keputusan Pembelian Konsumen. JMK (JURNAL MANAJEMEN \& KEWIRAUSAHAAN), VOL. 2, NO. 2, Mei 2017: 78-88

bps.go.id. 2019. Klasifikasi Baku Lapangan Usaha Indonesia (KBLI) Tahun 2015 Perka 2017 usaha Mikro dan Kecil. (Online). Tersedia: https://banten.bps.go.id/publication.html 
Darwanto et al., (2017). Pengembangan produksi usaha mikro, kecil dan menengah (UMKM) sector pertanian berbasis potensi local. Riset Ekonomi Manajemen http://jurnal.untidar.ac.id

Fitriani (2020). Pengaruh Kualitas Produk dan Kemasan terhadap Volume Penjualan. Business Preneur: Jurnal IImu Administrasi Bisnis Vol. 2 No. 1 (2020)

Kabar Banten. 26 November 2017. Warga Miskin Numpuk di Kasemen (Online). Tersedia: https://www.kabar-banten.com/warga-miskin-numpuk-di-kasemen/

Khasanah, Dwi Rohmawati. Sunarto dan Erry. (2021). Pengaruh kegiatan Pemasaran terhadap Peningkatan Hasil Produksi Jamur Tiram. Jurnal Manajemen dan Akuntansi Medan Vol. 3 No. 2 (2021).

Subali et al., (2020). Peningkatan Kuantitas dan Kualitas Produksi Kerupuk Basa di Desa Jegu, Kabupaten Tabanan. DINAMISIA: Jurnal Pengabdian Kepada Masyarakat Vol. 4, No. 4 Desember 2020, Hal. 730-736 DOI: https://doi.org/10.31849/dinamisia.v4i4.4625

Sudodo, Yandri (2019). Analisis Pengaruh Harga dan Kemasan Produk terhadap Keputusan Pembelian. JEBI: urnal Ekonomi dan Bisnis Indonesia, Vol. 04, No. 01 pp. 23-27 (2019) 